\title{
COMPARATIVE BIOLOGICAL RESISTANCE OF DIFFERENTLY THERMAL MODIFIED WOOD SPECIES AGAINST DECAY FUNGI, Reticulitermes grassei AND Hylotrupes bajulus
}

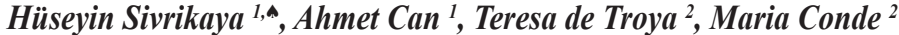

\begin{abstract}
Thermal modified wood has some advantages over natural wood, including decreased hygroscopicity, increased dimensional stability, and enhanced durability. In this study, European species of Scots pine (Pinus sylvestris), spruce (Picea orientalis), ash (Fraxinus spp.), and tropical species of tali (Erythrophleum ivorense), and iroko (Chlorophora excelsa) were thermally treated at $180^{\circ} \mathrm{C}$ and $210^{\circ} \mathrm{C}$ for 1,5 and $2 \mathrm{~h}$, respectively. We evaluated the resistances of the untreated and thermally treated samples to decay induced by the white rot fungus, Trametes versicolor and two brown rot fungi, Coniophora puteana and Postia placenta. In addition, the samples were exposed to the termite Reticulitermes grassei and the longhorn beetle species Hylotrupes bajulus to evaluate their resistance to damage by the insects. During the heat treatment, the mass loss of the samples generally was between 9 and $14 \%$. After the heat treatment, experiments were conducted to determine the effects of white and brown rot fungi on samples of Scots pine and tali, the effect of $C$. puteana on spruce, and the effects of $C$. puteana and P. placenta on ash and iroko. In all experiments, the mass loss due to damage from the various fungi was less than $1 \%$ for the samples that had been heat treated at $210{ }^{\circ} \mathrm{C}$. The untreated and heat-treated tropical species exhibited higher durability with very low mass loss and $100 \%$ mortality of the insects when attacked by termites, whereas the other wood species had moderate attack. In addition, Hylotrupes bajulus exposure by two standart methods (EN 46 and 47) resulted in similar performances in most cases, although EN 47 treated samples at $210{ }^{\circ} \mathrm{C}$ showed improved durability for Scots pine (Pinus sylvestris) and spruce (Picea orientalis).
\end{abstract}

Keywords: Decay resistance, longhorn beetle, termite, thermal treatment.

\section{INTRODUCTION}

Currently, heat treatment is one of the alternative treatments for the protection of wood. The aim of heat treatment is to increase the dimensional stability of the wood and its biological resistance to destructive organisms. In addition, heat treatment is applied to improve permeability and performance of preservatives such as CCA and CCB, the quality of surface treatments, and to reduce equilibrium moisture content (Boonstra et al. 2006, Unsal et al. 2003).

The heat treatment leads to significant changes in the chemical structure of the wood cell wall components such as cellulose, hemicellulose and lignin. The results are that the mechanical properties of the wood decrease, and dimensional stability and biological resistance of the wood increase (Tjeerdsma et al. 1998, Jamsa and Vitainemi 2001, Yildiz 2002, Petrissans et al. 2003, Gündüz et al. 2008, Can et al. 2010).

The reason of increasing in the biological resistance of wood by heat treatment was expressed as follow; 1) the decrease in the polysaccharide content, 2) the decrease in the moisture content, and 3) the loss of OH- groups from the walls of the cells. Thus, the normal enzymatic attack does not occur as quickly as it does with untreated wood (Stamm 1956, Hill 2006).

\footnotetext{
Bartin University, Faculty of Forestry 74100, Bartin, Turkey

${ }^{2}$ Laboratorio de Protección de Maderas CIFOR, INIA, Madrid, Spain

• Corresponding author: hsivrikaya@bartin.edu.tr

Received: 16.06.2014 Accepted: 09.12.2014
} 
During heat treatment, various organic compounds are produced, including phenolic compounds, phenantrene $\left(\mathrm{C}_{14} \mathrm{H}_{10}\right)$, polynuclear hydrocarbon derivatives, acenaphthylene $\left(\mathrm{C}_{12} \mathrm{H}_{8}\right)$, and other types of polyaromatic hydrocarbons. These toxic compounds produced by heat treatment slow or prevent fungal growth. However, some researchers have concluded that extracting these toxic compounds from the wood had no effect on fungal decay and had only a slight effect on rot resistance (Korkut and Kocaefe 2002).

On the other hand, the chemical composition of wood, such as the content of pinosylvin in pine heartwood, has been identified as an important factor that has an impact on decay resistance (Viitanen et al. 2006). This was found to be especially true for wood's content of acetyl groups, which is directly related to mass loss during heat treatment (Chaouch et al. 2010).

In addition, some authors have investigated whether the extractives affect the durability of heat-treated wood. Heat treatment causes the degradation of extractives in addition to the cell wall components, thereby changing the chemical composition of wood, depending on the heating time and the temperature (Bourgois et al. 1989, Esteves and Pereira 2009). Some explanations of the differences in durability of heat-treated wood species have been proposed. One such explanation is that the modified toxic extractives in heartwood and the others lignified cells in heartwood, limited diffusion and extraction of reactive intermediates in heartwood compared to sapwood. (Boonstra et al. 2007). Several phenolic compounds have been extracted from heat-treated radiata pine, with vanillin being the most significant because it shows decay resistance, particularly to P. placenta (Highley and Micales 1990).

Previous studies concerning the role of heat treatment in providing decay or insect resistance have focused on wood species with moderate or lower durability, such as Scots pine sapwood, spruce, and beech, which are very well known industrial species in the market. Likewise, some tropical species are known to have also low natural durability. However, the aim of this study was to determine the comparative performance, i.e., the resistance to decay and insect damage, of some heat-treated European woods and some tropical woods that are naturally durable and rich in extractives.

\section{MATERIALS AND METHODS}

Scots pine (Pinus sylvestris) sapwood, spruce (Picea orientalis), ash (Fraxinus spp.), tali (Erythrophleum ivorense), and iroko (Chlorophora excelsa) wood samples were obtained from a sawmill in Turkey. The wood moisture content was $10 \%$ before heat exposure. The heat treatment was applied on the timbers in a furnace at a temperature of $180^{\circ} \mathrm{C}$ for $1,5 \mathrm{~h}$ and at $210^{\circ} \mathrm{C}$ for $2 \mathrm{~h}$, respectively according to the Thermowood process in the presence of nitrogen. After heat treatment, the timbers were cut into small samples that measured $0,5 \times 1,5 \times 3 \mathrm{~cm}$ for the fungi test and $1,5 \times 2,5 \times 5 \mathrm{~cm}$ for the insect and termite tests.

The decay tests of white rot fungus, Trametes versicolor (L.: Fr.) Pilat and the brown rot fungi, Coniophora puteana (Schumach.) P. Karst. and Postia placenta (Fr.) M.J. Larsen \& Lombard were based on mini-block specimens on $48 \%$ malt extract agar in petri dishes. Six replicates were used for each test in the study as specified, with 90 control samples and 180 heat-treated samples. The treated and untreated samples were subjected to the decay test for eight weeks in a climate chamber at $25^{\circ} \mathrm{C}$ and $65 \% \mathrm{RH}$. At the end of the exposure time, the mycelia coverings on the sample surfaces were removed and weighed. The samples were weight oven-dried at $103{ }^{\circ} \mathrm{C}$ and reweighed. The mass loss was determined based on the dry weight before and after the decay test.

The methodology followed for the termite test with Reticulitermes grassei (Clement) is explained in the European Standard EN-117 (2012). In each test, a container was introduced containing moistened sand (one volume of water to four volumes of sand) and small pieces of wood (approximately $0,5 \mathrm{~g}$ ), which were pushed down to the bottom of the test container. Then, the termite colonies were place in the container, with each colony consisting of 250 workers and 2-3 soldiers and nymphs. The test containers were incubated in the culturing chamber, with air circulation, controlled at $26 \pm 2{ }^{\circ} \mathrm{C}$ and at a minimum relative humidity of $70 \pm 5 \%$. Over a period of two or four days 
after setting up the colonies, a glass ring was introduced against one of the vertical walls of the container, and each wood block test was introduced in the middle of the wall. All test containers with six replicates of wood samples were placed in the culturing chamber for a period of eight weeks with the humidity of the sand carefully controlled.

At the end of the test, the wood specimens were removed from the containers for visual examination, according to the following criteria: 0: no attack, 1: attempted attack (superficial erosion), 2: slight attack (erosion of $1 \mathrm{~mm}$ in depth and/or single tunneling to a depth of up to $3 \mathrm{~mm}$ ); 3 : average attack (erosion of $>1 \mathrm{~mm}$ in depth and/or isolated tunneling to a depth of $>3 \mathrm{~mm}$ without enlarging to form cavities), and 4: strong attack (erosion of $>1$ $\mathrm{mm}$ to $<3 \mathrm{~mm}$ in depth and/or tunneling penetrating to a depth $>3 \mathrm{~mm}$ and enlarging to form a cavity in the body of the test specimen). In addition, the total numbers of termites still living in the test containers were counted, and the survival levels of the workers were determined, as well as the presence of living soldiers and/or nymphs. Six replicates of wood samples were used for the insect test. Analysis of variance (ANOVA) was used to the data regarding with ML, degree of attack and mortality resulted from the termite test. Subsequently, mean values were compared with Tukey test $(\alpha=0,05)$.

The evaluation of the behavior of the heat-treated wood species against Hylotrupes bajulus (Linnaeus) was conducted according to the requirements of European Standards PrEN-46-1 (2008) and EN-47 (2004) with some modifications such as size of the wood specimens and number of them. In both methodologies, larvae within a maximum of three days of hatching were used.

In the EN-46 method, one glass plate was placed against one of the wide faces of each test specimen and fixed with paraffin wax along three edges. Then, six larvae were introduced in the middle part of the test section (between the glass and the wood). All wood blocks in these conditions were kept in the culturing chamber controlled at $28 \pm 2$ ${ }^{\circ} \mathrm{C}$ and $70 \pm 5 \%$ relative humidity for 24 weeks. After this period, the glass plate was carefully removed to ascertain the tunneling and mortality rate of the larvae, as well as the degree of attack.

In the Pr EN-47 method, a regular pattern of six holes approximately $3 \mathrm{~mm}$ deep was created in one of the wide longitudinal faces of each test specimen. Then, the larvae were carefully inserted head first while maintaining the holes in the samples in the upward position. Then, all samples were placed in the same testing chamber that was used for the EN-46 method and left for 24 weeks. After this time, the samples were evaluated to determine the mortality rate of the larvae, as well as the degree of attack. 


\section{RESULTS AND DISCUSSION}

\section{Mass loss}

Table 1 gives the mass losses (ML) of the different wood species during heat treatment.

ML was found to be similar for all wood species, about 9 to $11 \%$, for heat treatment at $180{ }^{\circ} \mathrm{C}$. ML for tali $(11 \%)$ was slightly greater than the losses for the other species, and might be due to the removal of more extractives.

Table 1. Mass losses of different wood species by heat treatment.

\begin{tabular}{lcc}
\hline Wood species & $\begin{array}{c}\text { Treatment } \\
\text { Temperature } \\
\left({ }^{\mathbf{0}} \mathbf{C}\right)\end{array}$ & Mass loss (\%) \\
\hline Scots pine & 180 & $9,8 \pm 0,6$ \\
& 210 & $13,6 \pm 1,1$ \\
Spruce & 180 & $10,2 \pm 0,8$ \\
& 210 & $14 \pm 1$ \\
Ash & 180 & $10,6 \pm 0,5$ \\
& 210 & $17,6 \pm 0,3$ \\
Iroko & 180 & $9,3 \pm 0,5$ \\
& 210 & $11,8 \pm 0,2$ \\
Tali & 180 & $11 \pm 0,3$ \\
& 210 & $14,7 \pm 0,3$ \\
\hline
\end{tabular}

ML for ash increased from $10,6 \%$ to $17,6 \%$ when the heat treatment temperature was $210{ }^{\circ} \mathrm{C}$. ML of the other species at this temperature were as follows: $14,7 \%$ for tali, $14 \%$ for spruce; $13,6 \%$ for Scots pine, and $11,8 \%$ for iroko.

ML that occurs during heat treatment of wood depends on the species of the wood, the heating medium, the treatment temperature, and the treatment time (Esteves and Pereira 2009). Alen et al. (2002), found ML for spruce to be $1,5 \%$ after $4 \mathrm{~h}$ of heating at $180{ }^{\circ} \mathrm{C}$ and $12,5 \%$ after $6 \mathrm{~h}$ of heating at $225^{\circ} \mathrm{C}$. ML for maritime pine in a hotair oven was obtained to be $3 \%$ at $180{ }^{\circ} \mathrm{C}$ in after $9 \mathrm{~h}$ and at $200{ }^{\circ} \mathrm{C}$ in $3 \mathrm{~h}$ (Esteves et al. 2008). $12 \% \mathrm{ML}$ was reached to the heat-treated beech wood under vacuum in the presence of nitrogen and steam when the temperature increased from $170{ }^{\circ} \mathrm{C}$ to $230{ }^{\circ} \mathrm{C}$ (Candelier et al. 2013). ML varied mostly between 9 and $13 \%$ in this experiment that might be attributed to the air-dry wood moisture content before heat treatment. Nevertheless, it was reasonably consistent with the results of previous studies in which the range was 9 to $14 \%$. This range of ML has been reported to be crucial to accomplish the highest durability against white and brown rot fungi (Hakkou et al. 2006, Mburu et al. 2007, Chaouch et al. 2010, Sustersic et al. 2010). 


\section{Decay resistance}

Table 2 shows the mean ML and standard deviations of different wood species caused by decay fungi.

Table 2. Mean mass losses and standard deviations of different wood species exposed to decay fungi.

\begin{tabular}{|c|c|c|c|}
\hline \multirow[b]{2}{*}{$\begin{array}{l}\text { Wood } \\
\text { species/Treatment, }\end{array}$} & \multicolumn{2}{|c|}{ Mass loss (\%) } & \multirow[b]{2}{*}{$\begin{array}{l}\text { Postia placento } \\
\text { Average }\end{array}$} \\
\hline & $\begin{array}{l}\text { Trametes versicolor } \\
\text { Average }\end{array}$ & $\begin{array}{l}\text { Coniophora puteana } \\
\text { Average }\end{array}$ & \\
\hline \multicolumn{4}{|l|}{$\begin{array}{l}\text { Scots pine (Pinus } \\
\text { sylvestris) }\end{array}$} \\
\hline Control & $18,7 \pm 9,6$ & $12,3 \pm 8,2$ & $9,56 \pm 5,8$ \\
\hline $180^{\circ} \mathrm{C}$ & $0,1 \pm 0,3$ & $1,4 \pm 2$ & $2 \pm 1,8$ \\
\hline $210^{\circ} \mathrm{C}$ & $0,4 \pm 0,6$ & $0,5 \pm 0,5$ & $0,2 \pm 2,6$ \\
\hline \multicolumn{4}{|l|}{$\begin{array}{l}\text { Spruce } \\
\text { (Picea orientalis) }\end{array}$} \\
\hline Control & $16,2 \pm 3,1$ & $32,8 \pm 5,1$ & $11 \pm 4,3$ \\
\hline $180^{\circ} \mathrm{C}$ & $12,6 \pm 2,4$ & $1,4 \pm 2,1$ & $5,4 \pm 3,5$ \\
\hline $210^{\circ} \mathrm{C}$ & $7,9 \pm 3$ & $0 \pm 0$ & $5,9 \pm 2,4$ \\
\hline \multicolumn{4}{|l|}{$\begin{array}{l}\text { Ash } \\
\text { (Fraxinus spp.) }\end{array}$} \\
\hline Control & $45,3 \pm 5,5$ & $12 \pm 6,6$ & $11,1 \pm 1,2$ \\
\hline $180^{\circ} \mathrm{C}$ & $21,8 \pm 6,9$ & $1,1 \pm 0,5$ & $2,5 \pm 1,4$ \\
\hline $210^{\circ} \mathrm{C}$ & $6,9 \pm 4,4$ & $0,5 \pm 0,8$ & $0 \pm 0$ \\
\hline \multicolumn{4}{|l|}{$\begin{array}{l}\text { Iroko (Chlorophora } \\
\text { excelsa) }\end{array}$} \\
\hline Control & $10,7 \pm 5,5$ & $3,3 \pm 1,5$ & $3,5 \pm 1$ \\
\hline $180^{\circ} \mathrm{C}$ & $1,9 \pm 0,9$ & $0,8 \pm 0,1$ & $0 \pm 0,7$ \\
\hline $210^{\circ} \mathrm{C}$ & $2,1 \pm 1,4$ & $0,7 \pm 0,4$ & $0,6 \pm 3,1$ \\
\hline \multicolumn{4}{|l|}{$\begin{array}{l}\text { Tali (Erythrophleum } \\
\text { ivorense) }\end{array}$} \\
\hline Control & $13,8 \pm 3,1$ & $0,1 \pm 0,2$ & $0,1 \pm 0,5$ \\
\hline $180^{\circ} \mathrm{C}$ & $0,7 \pm 0,9$ & $0,6 \pm 0,2$ & $0,7 \pm 0,2$ \\
\hline $210^{\circ} \mathrm{C}$ & $0 \pm 0$ & $0 \pm 0$ & $0 \pm 0$ \\
\hline
\end{tabular}

The white rot fungus, T. versicolor, substantially decayed the untreated ash samples, which showed $45,3 \% \mathrm{ML}$, whereas iroko had the least ML of $10,7 \%$. But, heat treatment at $180{ }^{\circ} \mathrm{C}$ significantly inhibited fungal attack on Scots pine $(0,1 \% \mathrm{ML})$, iroko $(1,9 \%)$, and tali $(0,7 \%)$, whereas spruce lost $12,6 \%$ and ash lost $21,8 \%$. Tali showed the highest resistance after heat treatment $210{ }^{\circ} \mathrm{C}$; the samples remained intact, and no ML occurred. At $210{ }^{\circ} \mathrm{C}$, spruce and ash had the most ML, just as they did when treated at $180^{\circ} \mathrm{C}$.

The white rot fungus T. versicolor substantially degraded the ash samples and caused ML of more than $10 \%$ for the naturally-durable, tropical species. This verified that white rot fungi preferentially attack hardwoods rather than softwoods (Enoki et al. 1988, Goodell et al. 2008, Ibach 2012).

The brown rot fungus, $C$. puteana caused the highest ML on the untreated spruce samples $(32,8 \%)$, and ML for Scots pine sapwood and ash were also quite high. However, iroko and tali showed significant resistance against this fungus. In addition, all wood species at $180^{\circ} \mathrm{C}$ showed higher resistant to C. puteana, with ML of less than $1,5 \%$ when compared to their untreated samples. Furthermore, the ML remained below $1 \%$ for all of the samples when the heat-treatment temperature was $210^{\circ} \mathrm{C}$; no attack was observed on the tali specimens at this condition. 
The another brown rot fungus $P$. placenta, caused about 10\% ML for the control samples of Scots pine, spruce, and ash, while it was $3,5 \%$ in iroko and $0,1 \%$ in tali. ML due to this fungus was generally decreased by increasing the heat-treatment temperature from $180^{\circ} \mathrm{C}$ to $210{ }^{\circ} \mathrm{C}$ in spite of the exceptional cases. The decay tests suggested that heat treatment can remarkably improve the durability of wood, depending on the species and treatment conditions, confirming the findings reported by Militz (2002).

Our results for increased decay resistance after heat treatment were similar to those reported by earlier researchers who investigated several fungi and different wood species. Dirol and Guyonnet 1993, studied the heat treatment of spruce, fir, and poplar based on the retification process in the temperatures range of $200^{\circ} \mathrm{C}$ to $260{ }^{\circ} \mathrm{C}$ to assess the decay resistance to white rot, Coriolus (Trametes) versicolor and two brown-rot fungi, i.e., Gloeophyllum trabeum and $C$. puteana. ML was found to be less than $1 \%$ for retified wood samples, whereas it was more than $40 \%$ for untreated samples. Weiland and Guyonnet (2003) obtained ML of 22,92\% and 5,94\% for untreated and heat-treated beech wood at 230 and $260{ }^{\circ} \mathrm{C}$ when the wood was subjected to P. placenta. In another study, the resistance of heat-treated spruce and pine to C. puteana was obtained at $220^{\circ} \mathrm{C}$, but not at 180 and $200{ }^{\circ} \mathrm{C}$, and higher ML were shown in untreated spruce (48 \%) and Scots pine (40 \%) (Rapp and Sailer 2001).

Untreated iroko and tali showed lower ML than other species against brown rot fungi, which might be explained by the higher extractive content of these species. Hakkou et al. (2006), investigated the influence of extractives on the decay resistance of beech wood. They heat treated extracted and unextracted beech wood in the broad temperature range of $20-280^{\circ} \mathrm{C}$ against $C$. versicolor and they concluded that there were quite small differences in $\mathrm{ML}$, indicating that the generation of extractives during heat treatment had no effect on decay resistance. Kamdem et al. (2002), extracted heat-treated wood samples with water and organic solvents but did not find any significant differences in ML for pine and spruce after the decay test.

\section{Insect resistance}

\section{Termite (Reticulitermes grassei)}

Table 3 gives ML, degree of attack, and mortality in relation to termite resistance of the untreated and heattreated samples. Table 4 shows the analysis of variance, table 5, demonstrates the Tukey test for those properties mentioned above.

Table 3. Evaluation of termite resistance (Reticutitermes grassei).

\begin{tabular}{|c|c|c|c|}
\hline Wood Species/Treatment & $\begin{array}{c}\text { Mass loss } \\
\% \\
\end{array}$ & Attack & $\begin{array}{c}\text { Mortality } \\
\%\end{array}$ \\
\hline \multicolumn{4}{|l|}{ Scots pine (Pinus sylvestris) } \\
\hline control & $10,1 \pm 1,5$ & $4,0 \pm 0$ & 40,6 \\
\hline $180^{\circ} \mathrm{C}$ & $11,4 \pm 1,6$ & $3,8 \pm 0,4$ & 28,1 \\
\hline $210^{\circ} \mathrm{C}$ & $6,8 \pm 6,2$ & $2,0 \pm 2,2$ & 64,5 \\
\hline \multicolumn{4}{|l|}{ Spruce (Picea orientalis) } \\
\hline control & $10,1 \pm 5,8$ & $3,3 \pm 1,6$ & 40 \\
\hline $180^{\circ} \mathrm{C}$ & $10,1 \pm 6,7$ & $3,2 \pm 1,6$ & 52,2 \\
\hline $210^{\circ} \mathrm{C}$ & $18,4 \pm 6$ & $4,0 \pm 0$ & 21,7 \\
\hline \multicolumn{4}{|l|}{ Ash (Fraxinus spp.) } \\
\hline control & $7,8 \pm 1,3$ & $3,2 \pm 1,2$ & 48,9 \\
\hline $180^{\circ} \mathrm{C}$ & $7,5 \pm 2,7$ & $3,3 \pm 1,6$ & 42,5 \\
\hline $210^{\circ} \mathrm{C}$ & $8,4 \pm 2,9$ & $3,3 \pm 0,8$ & 38,6 \\
\hline \multicolumn{4}{|l|}{ Iroko (Chlorophora excelsa) } \\
\hline control & $0,4 \pm 0,2$ & $0 \pm 0$ & 100 \\
\hline $180^{\circ} \mathrm{C}$ & $1,6 \pm 0,8$ & $0,3 \pm 0$ & 100 \\
\hline $210^{\circ} \mathrm{C}$ & $2,2 \pm 0,8$ & $0,3 \pm 0,5$ & 100 \\
\hline \multicolumn{4}{|l|}{ Tali (Erythrophleum ivorense) } \\
\hline control & $0,3 \pm 0,1$ & $0 \pm 0$ & 100 \\
\hline $180^{\circ} \mathrm{C}$ & $0,8 \pm 0,3$ & $0 \pm 0$ & 100 \\
\hline $210^{\circ} \mathrm{C}$ & $1,5 \pm 0,2$ & $0,2 \pm 0,4$ & 100 \\
\hline
\end{tabular}


Table 4. Variance analysis (ANOVA) for the termite test including mass loss, attack and mortality.

\begin{tabular}{|c|c|c|c|c|c|c|}
\hline \multirow{6}{*}{ Mass loss } & & Sum of Squares & $\mathrm{df}$ & Mean Square & $\mathrm{F}$ & Sig \\
\hline & Between & 2327,782 & 14 & \multirow{3}{*}{166,270} & & \multirow{5}{*}{0} \\
\hline & Groups & & & & & \\
\hline & Within & 882,980 & 75 & & 14,123 & \\
\hline & Groups & & & \multirow[t]{2}{*}{11,773} & & \\
\hline & Total & 3210,762 & 89 & & & \\
\hline \multirow{5}{*}{ Attack } & Between & & \multirow{5}{*}{14} & \multirow{5}{*}{$\begin{array}{c}17,257 \\
1,040\end{array}$} & \multirow{5}{*}{16,593} & \multirow{5}{*}{0} \\
\hline & Groups & 241,600 & & & & \\
\hline & Within & & & & & \\
\hline & Groups & 319,600 & & & & \\
\hline & Total & & & & & \\
\hline \multirow{5}{*}{ Mortality } & Between & & \multirow{5}{*}{14} & \multirow{5}{*}{$\begin{array}{c}35987,381 \\
2922,736\end{array}$} & \multirow{5}{*}{12,313} & \multirow{5}{*}{0} \\
\hline & Groups & 503823,333 & & & & \\
\hline & Within & 219205,167 & & & & \\
\hline & Groups & 723028,500 & & & & \\
\hline & Total & & & & & \\
\hline
\end{tabular}

According to variance analysis the difference with regard to ML, degree of attack and mortality was found significantly (Table 4). The differences between wood species and heat treatment were indicated by Tukey test (Table 5).

Table 3 indicates that the Scots pine control samples were strongly attacked by the termite species with an attack of 4 and $40,6 \%$ mortality. Even though heat treatment at $180{ }^{\circ} \mathrm{C}$ did not improve the termite resistance, the specimens gained resistance to termites after they were heat treated at $210^{\circ} \mathrm{C}$, with decreases in their ML, reduced levels of attack, and higher mortality of the workers (about 65\%).

Unlike the Scots pine samples, spruce specimens were not found to be effective against termites when heat treated at $210^{\circ} \mathrm{C}$, which revealed higher ML and lower mortality. However, very similar ML was indicated statistically to Scots pine and spruce at $180{ }^{\circ} \mathrm{C}$ and for their controls (Table 5).

Table 5. Tukey test for mass loss, termite attack and mortality (number of the dead workers) after termite test $(\alpha=0,05)$.

\begin{tabular}{|c|c|c|c|c|c|c|}
\hline $\begin{array}{c}\text { Wood } \\
\text { Species/Treatment }\end{array}$ & $\mathbf{N}$ & Mass loss & Treatment & $\begin{array}{c}\text { Termite } \\
\text { attack }\end{array}$ & Treatment & Mortality \\
\hline tali control & 6 & 0,29 (a) & iroko control & $O(a)$ & spruce $210^{\circ} \mathrm{C}$ & $54,33(a)$ \\
\hline iroko control & 6 & 0,42 (a) & tali control & $0(a)$ & $\begin{array}{l}\text { Scots pine } 180 \\
{ }^{\circ} \mathrm{C}\end{array}$ & $70,17(a)$ \\
\hline tali $180^{\circ} \mathrm{C}$ & 6 & $0,76(\mathrm{ab})$ & tali $180^{\circ} \mathrm{C}$ & $O(a)$ & $\operatorname{ash} 210^{\circ} \mathrm{C}$ & $96,50(a)$ \\
\hline tali $210^{\circ} \mathrm{C}$ & 6 & $1,51(\mathrm{abc})$ & tali $210^{\circ} \mathrm{C}$ & 0,17 (a) & spruce control & $100(a)$ \\
\hline iroko $180^{\circ} \mathrm{C}$ & 6 & $1,60(a b)$ & iroko $180^{\circ} \mathrm{C}$ & $0,33(a)$ & $\begin{array}{l}\text { Scots pine } \\
\text { control }\end{array}$ & $101,50(a)$ \\
\hline iroko $210^{\circ} \mathrm{C}$ & 6 & $2,18(a b c)$ & iroko $210^{\circ} \mathrm{C}$ & $0,33(a)$ & $\operatorname{ash} 180^{\circ} \mathrm{C}$ & 106,17 (a) \\
\hline Scots pine $210^{\circ} \mathrm{C}$ & 6 & $6,79($ abcd $)$ & $\begin{array}{l}\text { Scots pine } 210 \\
{ }^{\circ} \mathrm{C}\end{array}$ & $2(a b)$ & ash control & 122,17 (a) \\
\hline $\operatorname{ash} 180^{\circ} \mathrm{C}$ & 6 & $7,48(\mathrm{bcd})$ & spruce $180^{\circ} \mathrm{C}$ & $3,17(b)$ & spruce $180^{\circ} \mathrm{C}$ & $130,50(a)$ \\
\hline ash control & 6 & $7,80(\mathrm{~cd})$ & ash control & 3,17 (b) & $\begin{array}{l}\text { Scots pine } 210 \\
{ }^{\circ} \mathrm{C}\end{array}$ & $161,17(\mathrm{ab})$ \\
\hline $\operatorname{ash} 210^{\circ} \mathrm{C}$ & 6 & $8,44(\mathrm{~cd})$ & spruce control & $3,33(b)$ & iroko control & $250(b)$ \\
\hline Scots pine control & 6 & $10,10(\mathrm{~d})$ & ash $180^{\circ} \mathrm{C}$ & 3,33 (b) & iroko $180^{\circ} \mathrm{C}$ & $250(b)$ \\
\hline Spruce control & 6 & $10,11(d)$ & $\operatorname{ash} 210^{\circ} \mathrm{C}$ & 3,33 (b) & iroko $210^{\circ} \mathrm{C}$ & $250(b)$ \\
\hline Spruce $180^{\circ} \mathrm{C}$ & 6 & $10,13(d)$ & $\begin{array}{l}\text { Scots pine } 180 \\
{ }^{\circ} \mathrm{C}\end{array}$ & $3,83(b)$ & tali control & $250(b)$ \\
\hline Scots pine $180^{\circ} \mathrm{C}$ & 6 & $11,41(d)$ & $\begin{array}{l}\text { Scots pine } \\
\text { control }\end{array}$ & 4(b) & tali $180^{\circ} \mathrm{C}$ & $250(b)$ \\
\hline Spruce $210^{\circ} \mathrm{C}$ & 6 & $18,42(\mathrm{e})$ & spruce $210^{\circ} \mathrm{C}$ & 4(b) & tali $210^{\circ} \mathrm{C}$ & $250(b)$ \\
\hline
\end{tabular}

Scots pine (Pinus sylvestris), spruce (Picea orientalis), ash (Fraxinus spp.), tali (Erythrophleum ivorense), and iroko (Chlorophora excelsa) 
Control specimens of spruce and that heat treated at $180{ }^{\circ} \mathrm{C}$ had similar values with regard to $\mathrm{ML}$ and degree of attack; however, the mortality rate of the workers increased from $40 \%$ (100 dead of 250 workers) to $52 \%$ (130 dead of 250 workers) which was not found statistically significant as shown in table 5. It was interesting that heavy attacks occurred for specimens heat-treated at $210{ }^{\circ} \mathrm{C}$, and $\mathrm{ML}$ was around $18 \%$, while $78 \%$ of the workers remained alive. Heat treatment did not enhance the termite resistance of the ash specimens, and the survival rate of the workers gradually increased irrespective of the increase in temperature.

Based on visual examination and ML determination, the tropical species demonstrated excellent termite resistance for both untreated and heat-treated samples. Untreated iroko wood exhibited performance as good as the heat-treated samples. This experiment revealed complete mortality in all cases in spite of the minor increase in ML and termite attack that appeared on the heat-treated samples.

Heat treatment of the tali samples displayed almost the same results as iroko against termites. It can be seen from the Tukey test in table 5, there is significantly difference in the degree of termite attack between tropical and other wood species. The very low increase in ML by heat treatment might be caused by the removal of extractives, since there was almost no attack; also, none of the workers survived when they were exposed to the untreated and the heat-treated samples. The significant difference was found to the number of dead workers between tropical and other species, indicated statistically in table 5 .

The increase in the mortality of the workers in Scots pine as the heat-treatment temperature increased may be attributed to the toxic compounds that were generated during the heat treatment. According to Esteves and Pereira (2009), while some extractives are degraded during heat treatment, new compounds are formed from the degradation products of the wood's cells. However, based on the results of this study, it cannot be definitely stated that the extractives that were generated in the tropical species during heat treatment had an effect on termite resistance. This is due to the fact that the controls of the tropical species revealed excellent performance against termites as well, and full mortality was probably due to the excessive extractive content. The mortality may be explained by the formation of toxic components as a result of degradation, which were consumed by the termites (Surini et al. 2012). They used maritime pine samples exposed to heat treatment under vacuum pressure, which were severely degraded by termites (R. santonensis) even though the heat treatment temperature was $230^{\circ} \mathrm{C}$; below $200{ }^{\circ} \mathrm{C}$, the mortality rate was found to be between 50 and $55 \%$. At $230^{\circ} \mathrm{C}$, the mortality rate was $70,4 \%$. For comparison, the mortality rate was $39,2 \%$ for the untreated control samples.

Shi et al. (2007), demonstrated significantly greater termite attack on thermally treated Scots pine at $210{ }^{\circ} \mathrm{C}$ for 15 min than on untreated controls, and they concluded that the toxic compounds in Scots pine showed an inhibition effect to termites (R. flavipes). ML of Scots pine was 10,3\% for untreated control, whereas it was $33,6 \%$ for the heat-treated samples. However, in the same study, the heat-treated samples of other species, i.e., aspen, jack pine, and yellow poplar, had performances similar to that of the untreated controls against termites.

In another study, Grevillea robusta, which is a tropical species that has low natural durability, was severely degraded by the termite species Macrotermes natalensis, exceeding even that of untreated Scots pine, but it showed significant resistance when it had been heat treated at $250{ }^{\circ} \mathrm{C}$ for $7 \mathrm{~h}$ (Mburu et al. 2007).

\section{Longhorn beetle (Hylotrupes bajulus)}

The performance of the untreated and treated samples to the insect larvae was evaluated based on the EN 46 and EN 47 standards in table 6. The values obtained using EN 47 are indicated with asterisks in the table 6. 
Table 6. Assesment of the samples against Hylotrupes bajulus according to EN 46 (without asterisk) and EN47 (*).

\begin{tabular}{|c|c|c|c|c|}
\hline & \multirow{4}{*}{ Attack } & \multicolumn{3}{|c|}{ Larvae recovered } \\
\hline & & \multicolumn{2}{|c|}{ Dead } & \multirow[b]{2}{*}{$\begin{array}{l}\text { Live after } \\
\text { tunelling }\end{array}$} \\
\hline & & $\begin{array}{c}\text { Not } \\
\text { having } \\
\text { tunnelled }\end{array}$ & $\begin{array}{l}\text { Having } \\
\text { tunnelled }\end{array}$ & \\
\hline \multicolumn{4}{|c|}{$\begin{array}{c}\text { Scots pine } \\
\text { (Pinus sylvestris) }\end{array}$} & \\
\hline control & $1-2 *$ & $3-0 *$ & $3-1 *$ & $0-5 *$ \\
\hline $180^{\circ} \mathrm{C}$ & $0-1 *$ & $5-0 *$ & $1-6^{*}$ & $0-0 *$ \\
\hline $210^{\circ} \mathrm{C}$ & $0-0^{*}$ & $2-2 *$ & $4-4 *$ & $0-0 *$ \\
\hline \multicolumn{5}{|c|}{$\begin{array}{c}\text { Spruce } \\
\text { (Picea orientalis) }\end{array}$} \\
\hline Control & $1-2^{*}$ & $2-2 *$ & $4-0 *$ & $0-4^{*}$ \\
\hline $180^{\circ} \mathrm{C}$ & $1-1^{*}$ & $3-4 *$ & $3-2 *$ & $0-0 *$ \\
\hline $210^{\circ} \mathrm{C}$ & $0-0 *$ & $6-6^{*}$ & $0-0 *$ & $0-0 *$ \\
\hline \multicolumn{5}{|c|}{$\begin{array}{c}\text { Ash } \\
\text { (Fraxinus spp.) }\end{array}$} \\
\hline Control & $0-0 *$ & $6-6^{*}$ & $0-0 *$ & $0-0 *$ \\
\hline $180^{\circ} \mathrm{C}$ & $0-0 *$ & $6-6 *$ & $0-0 *$ & $0-0 *$ \\
\hline $210^{\circ} \mathrm{C}$ & $0-0 *$ & $6-6^{*}$ & $0-0 *$ & $0-0 *$ \\
\hline \multicolumn{5}{|c|}{$\begin{array}{c}\text { Iroko } \\
(\text { Chlorophora excelsa) }\end{array}$} \\
\hline Control & $0-0 *$ & $6-6^{*}$ & $0-0 *$ & $0-0 *$ \\
\hline $210^{\circ} \mathrm{C}$ & $0-0 *$ & $6-6^{*}$ & $0-0 *$ & $0-0 *$ \\
\hline $210^{\circ} \mathrm{C}$ & $0-0 *$ & $6-6^{*}$ & $0-0 *$ & $0-0 *$ \\
\hline \multicolumn{5}{|c|}{$\begin{array}{c}\text { Tali } \\
\text { (Erythrophleum } \\
\text { ivorense) }\end{array}$} \\
\hline Control & $0-0 *$ & $6-6^{*}$ & $0-0 *$ & $0-0 *$ \\
\hline $180^{\circ} \mathrm{C}$ & $0-0 *$ & $6-6 *$ & $0-0 *$ & $0-0 *$ \\
\hline $210^{\circ} \mathrm{C}$ & $0-0 *$ & $6-6^{*}$ & $0-0 *$ & $0-0 *$ \\
\hline
\end{tabular}

\section{Evaluation to the EN 46}

Table 6 indicates that $H$. bajulus performed superficial attack on untreated Scots pine, while no attack was observed on samples heat treated at $180^{\circ} \mathrm{C}$ and $210^{\circ} \mathrm{C}$. Five of the insects were found dead without having made tunnels when they were exposed to Scots pine that had been heated at $180^{\circ} \mathrm{C}$; one insect was able to tunnel before dying. When the temperature reached to $210^{\circ} \mathrm{C}$, four dead insects had made tunnels into Scots pine, and two had not.

Spruce samples heated at $210^{\circ} \mathrm{C}$ showed better resistance than its controls and samples heated at $180^{\circ} \mathrm{C}$, because no attack occurred; in addition all of the larvae were found dead without having made tunnels.

As for ash, iroko and tali, no differences were found for control and heat-treated samples in their resistance to $H$. bajulus. All of the samples remained intact after 24 months of exposure, and none of the insects managed to create tunnels, and they eventually died. This implied that these wood species showed great resistance to H. bajulus with or without thermal treatment. 


\section{Evaluation to the EN 47}

In this experiment, heating Scots pine at $210^{\circ} \mathrm{C}$ enhanced its insect resistance since no attack appeared. There were slight attacks on the control samples and superficial attacks on the samples that were heat treated at $180^{\circ} \mathrm{C}$. In addition, five larvae were still alive in the control case, whereas none was found on the heat-treated samples after the exposure period.

As with Scots pine, no attacks were observed on spruce that had been heat treated at $210{ }^{\circ} \mathrm{C}$; in addition, there were no tunnels or live insects in the wood that had been treated at this temperature, but four larvae were still alive on control samples of spruce. These results indicated that Scots pine and spruce gained resistance against $H$. bajulus after heat treatment at $210{ }^{\circ} \mathrm{C}$. Higher resistance of heat-treated wood against the longhorn beetles, Anobium punctatum and Lyctus brunneus before was reported by Mayes and Oksanen (2002).

As for ash, iroko, and tali, EN 47 absolutely conformed to EN 46 in all cases, meaning that the control samples and the heat-treated samples had exactly the same results in terms of the insects' attacks, tunneling, and survival. Both standards demonstrated that untreated and heat-treated samples of ash, iroko, and tali had the same resistance against $H$. bajulus.

\section{CONCLUSIONS}

The results of this study showed that high-temperature heat treatment and treatment time, as expected, produced mass losses that were similar in the tropical specimens and the other species of wood. Heat treatment significantly enhanced the decay resistance against white and brown rot fungi. For the tropical species, the improvement in decay resistance was very significant against the white rot fungus $T$. versicolor.

Untreated and heat-treated tropical woods inhibited termite attacks to a significant extent, and all of the termites died. However, all other species were degraded by termites irrespective of the treatment temperature. In addition, the test results showed that there was a good correlation between the mass loss and the extent of the termite attacks.

According to EN 47, the heat treatment of Scots pine and spruce at $210{ }^{\circ} \mathrm{C}$ provided resistance against $H$. bajulus. EN 46 and EN 47 showed similar results in terms of the effectiveness of heat treatment against insects.

It is generally known that most of the extractives are removed during the thermal treatment process, but this research showed that tropical woods rich in extractives did not lose efficiency to microorganisms after treatment.

Further studies may be carried out with naturally-durable tropical species after extractives were removed to better understand the effect of extractives on decay and insect resistance. The results of this study also indicated that heat treatment is a valuable and environmentally-friendly method for improving the biological resistance of wood.

\section{ACKNOWLEDGEMENTS}

The authors would like to thank the undergraduate student İlknur Tekin for the help with decay test and Dr. Kenan Melemez for statistical analysis. 


\section{REFERENCES}

Alen, R.; Kotilainen, R.; Zaman, A. 2002. Thermochemical behavior of Norway spruce (Picea abies) at 180-225 ${ }^{\circ} \mathrm{C}$. Wood Sci Technol 36(2): 163-171.

Boonstra, M.J.; Rijsdijk, J.F.; Sander, C.; Kegel, E.; Tjeerdsma, B.; Militz, H.; Van Acker, J.; Stevens M. 2006. Microstructural And Physical Aspects Of Heat Treated Wood. Part 2. Hardwoods. Maderas. Ciencia y tecnología 8(3): 209-217.

Boonstra, M.J.; Van Acker, J.; Kegel, E.; Stevens, M. 2007. Optimisation of the two-stage heat treatment process: durability aspects. Wood Sci Technol 41:31-57

Bourgois, J.; Bartholin, M.; Guyonnet, R. 1989. Thermal treatment of wood: analysis of the obtained product. Wood Sci Technol 23:303-310

Can, A.; Yıldız, S.; Yıldız, Ü.C.; Tomak, E.D. 2010. Effects of Boron Impregnation and Heat Treatment on the Some Physical and Mechanical Properties of Spruce and Pine Wood, 1.Uluslararası Türk-Japon Çevre ve Ormanc1lık Sempozyumu, Kasım, Trabzon, Bildiriler kitabı II: 753-766.

Candelier, K.; Dumarçay, S.; Petrissans, A.; Desharnais, L.; Gérardin, P.; Petrissans, M. 2013. Comparison of chemical composition and decay durability of heat treated wood cured at a same temperature under different inert atmospheres: nitrogen or vacuum. Polymer Degradation and Stability 98(2): 677-681.

Chaouch, M.; Pétrissans, M.; Pétrissans, A.; Gérardin, P. 2010. Use of wood elemental composition to predict heat treatment intensity and decay resistance of different softwood and hardwood species. Polymer Degradation and Stability 95: 2255-2259.

Dirol, D.; Guyonnet, R. 1993. The improvement of wood durability by retification process. International research groups on wood preservation. IRG/WP 93-40015, Section 4. 24 Annual meeting, May 16-21 Orlando.

EN-46-1. 2008. Wood Preservatives - Determination of the Preventive Action against Recently Hatched Larvae of Hylotrupes bajulus (Linnaeus) - Part 1: Application by Surface Treatment (Laboratory Method).

EN 47. 2004. Wood preservatives - Determination of the toxic values against larvae of Hylotrupes bajulus (Linnaeus) (Laboratory method).

EN 117. 2012. Wood preservatives - Determination of toxic values against Reticulitermes species (European termites) (Laboratory method).

Enoki, A.; Tanaka, H.; Fuse, G. 1988. Degradation of lignin related compounds, pure cellulose and wood components by white-rot and brown-rot fungi. Holzforschung 42: 85-93.

Esteves, B.; Domingos, I.; Pereira, H. 2008. Pine wood modification by heat treatment in air. BioRes 3(1):142-154.

Esteves, B.; Pereira, H. 2009. Wood modification by heat treatment: a review. BioRes 4(1):370-404.

Goodell, B.; Qian, Y.; Jellison, J. 2008. Fungal Decay of Wood: Soft Rot—Brown Rot—White Rot, Development of Commercial Wood Preservatives Chapter 2, pp 9-31, ACS Symposium Series, Vol. 982.

Gündüz, G.; Korkut, S.; Korkut, D.S. 2008. The effects of heat treatment on physical and technological properties and surface roughness of Camiyanı Black Pine (Pinus nigra Arn. subsp. pallasiana var. pallasiana) wood. Biores Technol 99(7): 2275-2280.

Hakkou, M.; Pétrissans, M.; Gérardin, P.; Zoulalian, A. 2006. Investigations of the reasons for fungal durability of heat-treated beech wood. Polymer Degradation and Stability 91(2):393-397.

Highley, T.L.; Micales, J.A. 1990. Effect of aromatic monomers on production of carbohydratedegrading enzymes by white-rot and brown-rot fungi. FEMS Microbiol Lett 66:15-22. 
Hill, C.A.S. 2006. Wood modification: Chemical, thermal and other processes. John Wiley \& Sons, Chichester. UK.

Ibach, R.E. 2012. Biological properties of wood. R.M. Rowell (Ed.), Chemical Modification of Wood (second ed.), CRC Press, United States of America.

Jamsa, S.; Viitaniemi, P. 2001. Heat treatment of wood better durability without chemicals. In: Rapp A.O. (Ed.), Review on Heat Treatments of Wood. Cost Action E22. Proceedings of the Special Seminar, Antibes, France, pp. 17-22.

Kamdem, D.M.; Pizzi, A.; Jermannaud, A. 2002. Durability of heat-treated wood. Holz als Roh und Werkstoff 60(1):1-6.

Korkut, S.; Kocaefe, D. 2002. Isıl İşlemin Odun Özellikleri Üzerine Etkisi. Düzce Üniversitesi Ormancllk Dergisi $5(2): 11-34$.

Mayes, D.; Oksanen, 0. 2002. ThermoWood Handbook. By: Thermowood, Finnforest, Stora.

Mburu, F.; Dumarçay, S.; Huber, F.; Pétrissans, M.; Gérardin, P. 2007. Evaluation of thermally modified Grevillea robusta heartwood as an alternative to shortage of wood resource in Kenya: characterisation of physicochemical properties and improvement of bio-resistance. Bioresource Technology 98(18): 3478-3486.

Militz, H. 2002. Thermal treatment of wood: European Processes and their background. IRG/WP 02-40241, 33rd Annual meeting Cardiff, UK.

Petrissans, M.; Gerardin, P.; Elbakali, D.; Serraj, M. 2003. Wettability of heat-treated wood. Holzforschung 57:301-307.

Rapp, A.O.; Sailer, M. 2001. Oil heat treatment of wood in Germany: state of the art. In: Rapp, A.O. (Ed.), Review on Heat Treatments of Wood. In: Special Seminar: Environmental Optimisation of Wood Protection, Antibes, France. Proceedings, Cost Action E 22, pp. 47-64.

Shi, J.L.; Kocaefe, D.; Amburgey, T.; Zhang, J. 2007. Acomparative study on brown-rot fungus decay and subterranean termite resistance of thermally-modified andACQ-C-treatedwood. Holz Roh Werkst 65: 353-358.

Stamm, A.J. 1956. Thermal Degradation of Wood and Cellulose. Ind Eng Chem 48(3): 413-417.

Surini, T.; Charrier, F.; Malvestio, J.; Charrier, B.; Moubarik, A.; Castéra, P.; Grelier, S. 2012. Physical properties and termite durability of maritime pine Pinus pinaster Ait., heat-treated under vacuum pressure. Wood Science and Technology 46: 487-501.

Sustersic, Z.; Mohareb, A.; Chaouch, M.; Pétrissans, M.; Petric, M.; Gérardin, P. 2010. Prediction of decay resistance of heat treated wood on the basis of its elemental composition. Polymer Degradation and Stability 95(1): 94-97.

Tjeerdsma, B.F.; Boonstra, M.; Pizzi, A.; Tekely, P.; Militz, H. 1998. Characterisation of thermally modified wood: molecular reasons for wood performance improvement. Holz Roh Werkst 56:149-153.

Unsal, O.; Korkut, S.; Atik, C. 2003. The Effect Of Heat Treatment On Some Properties And Colour In Eucalyptus (Eucalyptus Camaldulensis Dehn.) Wood, Maderas. Ciencia y Tecnología 5(2): 145-152.

Viitanen, H.; Metsa-Kortelainen, S.; Laakso, T. 2006. Resistance of pine and spruce heartwood against decay. The effect of wood chemical composition and coating with water-borne wood oil product IRG/WP 06-10597, 37th Annual Meeting Tromsø, Norway.

Weiland, J.J.; Guyonnet, R. 2003. Study of chemical modifications and fungi degradation of thermally-modified wood using DRIFT spectroscopy. Holz Roh-Werkst 61(2): 216-220.

Yıldız, S. 2002. Isıl işlem uygulanan Doğu Kayını ve Doğu Ladini Odunlarının Fiziksel Teknolojik ve Kimyasal Özellikleri, Doktora Tezi, K.T.Ü., Fen Bilimleri Enstitüsü, Trabzon. 